\title{
Analisis Kemampuan Berpikir Kritis Siswa SMP terhadap mata pelajaran IPA Melalui Penggunaan Media Google Classroom
}

\author{
Meriyanti $^{1}$, Rina Hidayati Pratiwi2*, Efri Gresinta ${ }^{1}$, Endang Sulistyaniningsih ${ }^{3}$ \\ ${ }^{1}$ Program Studi S-1 Pendidikan Biologi, Fakultas Matematika dan Ilmu Pengetahuan Alam, \\ Universitas Indraprasta PGRI, Indonesia \\ ${ }^{2}$ Program Studi S-2 Pendidikan MIPA, Fakultas Pasca Sarjana, Universitas Indraprasta PGRI, \\ Indonesia \\ 3 Program Studi S-1 Teknik Informatika, Fakultas Teknik dan llmu Komputer, Universitas \\ Indraprasta PGRI, Indonesia
}

*Email: rina.hp2012@gmail.com

\begin{tabular}{|c|c|}
\hline Info Artikel & Abstrak \\
\hline $\begin{array}{l}\text { Diterima:17 Februari } \\
2021 \\
\text { Direvisi: } 1 \text { November } \\
2021 \\
\begin{array}{l}\text { Diterima } \\
\text { untuk diterbitkan: } \quad 4 \\
\text { November } 2021\end{array}\end{array}$ & $\begin{array}{l}\text { Di era saat ini siswa kurang mendalami pembelajaran yang didapat, salah } \\
\text { satu faktor penyebabnya adalah kurangnya inovasi dalam media } \\
\text { pembelajaran. Media pembelajaran merupakan salah satu faktor penting } \\
\text { dalam menunjang proses pembelajaran.. Penggunaan media pembelajaran } \\
\text { google classroom diharapkan dapat merangsang keterlibtan siswa dalam } \\
\text { kegiatan pembelajaran dengan mengajak siswa untuk berpartisipasi aktif } \\
\text { dalam proses pembelajaran sehingga dapat menjadi solusi yang tepat }\end{array}$ \\
\hline $\begin{array}{l}\text { Keywords: } \\
\text { Berpikir Kritis, Google } \\
\text { Classroom, IPA }\end{array}$ & $\begin{array}{l}\text { dalam meningkatkan kemampuan berpikir kritis khususnya pada mata } \\
\text { pelajaran IPA. Tujuan penelitian ini adalah untuk mengetahui analisis } \\
\text { kemampuan berpikir kritis IPA melalui penggunaan media google } \\
\text { classroom di SMP Lamaholot Cengkareng. Metode penelitian yang } \\
\text { digunakan adalah metode kualitatif dengan jenis penelitian analisis } \\
\text { kualitatif Subjek dalam penelitian ini adalah siswa kelas VII SMP } \\
\text { Lamaholot Cengkareng yang berjumlah } 20 \text { siswa. Teknik pengumpulan } \\
\text { data dalam penelitian ini menggunakan wawancara, observasi, dan tes } \\
\text { deskripsi yang berupa tes tertulis. Teknik analisis data dalam penelitian ini } \\
\text { menggunakan analisis deskriptif. Hasil penelitian menunjukkan bahwa } \\
\text { siswa kelas VII SMP Lamaholot Cengkareng memiliki kemampuan } \\
\text { berpikir kritis yang tinggi dengan rata- rata } 86,8 \text { dengan indikator tertinggi } \\
\text { adalah strategi dan taktik dengan persentase } 92 \% \text { sedangkan indikator } \\
\text { terendah adalah menarik kesimpulan dengan persentase persentase } 80 \text {, } \\
25 \% \text {. }\end{array}$ \\
\hline
\end{tabular}

(C) 2021 Universitas Bengkulu. This is an open-access article under the CC-BY license (https://creativecommons.org/licenses/by/4.0)

\section{PENDAHULUAN}

Pendidikan merupakan suatu proses pembelajaran untuk menggali dan mengembangkan potensi-potensi yang dimiliki seseorang dengan upaya pelatihan dan pengajaran yang dapat 
dilakukan di sekolah maupun di luar sekolah. Pendidikan juga dapat membantu seseorang dalam proses pendewasaan diri. Terdapat tiga jenis pendidikan yang ada di Indonesia yaitu pendidikan formal, pendidikan non formal dan pendidikan informal. Pendidikan formal merupakan pendidikan yang terstruktur dan memiliki jenjang, biasanya dimulai dari pendidikan anak usia dini (PAUD) sampai pendidikan tinggi (Universitas). Pendidikan non formal merupakan jalur pendidikan di luar pendidikan formal, namun pelaksanaannya masih terstruktur dan berjenjang, seperti lembaga kursus, lembaga pelatihan, dan sanggar. Pendidikan informal merupakan pendidikan yang dapat diperoleh melalui keluarga dan lingkungan sekitar, seperti moral, etika, dan budi pekerti. Salah satu tujuan dari pendidikan adalah untuk mencerdaskan kehidupan bangsa. Dalam proses berlangsungnya pendidikan, terdapat berbagai macam karakter dan pola pikir yang berbeda dari setiap siswa. Cara berpikir siswa sangat berpengaruh dalam mengembangkan pola pikir, salah satunya mengembangkan kemampuan berpikir kritis. Seiring berjalannya zaman, siswa semakin dituntut untuk mengembangkan kemampuan berpikir kritis, terlebih dikemajuan teknologi saat ini. Berpikir kritis merupakan suatu pikiran yang difokuskan untuk memutuskan apa yang diyakini untuk dilakukan (Mahmuzah, 2015). Seseorang yang memiliki karakter berpikir kritis biasanya memiliki pemikiran yang luas dan terbuka, fokus pada kejelasan dan ketelitian, serta menerima pendapat-pendapat lain yang berbeda. Seseorang yang memiliki karakter berpikir kritis akan berubah pandangan jika menemukan pendapat lain yang menurutnya lebih baik. Menurut Wijaya (2010) berpikir kritis yaitu kegiatan menganalisis ide atau gagasan ke arah yang lebih spesifik, membedakannya secara tajam, memilih, mengidentifikasi, mengkaji, dan mengembangkannya kearah yang lebih sempurna.

Dalam proses pembelajaran di kelas tentunya tidak lepas dari peran guru. Guru juga bertugas untuk memberikan kenyamanan dalam proses pembelajaran di kelas maupun di luar kelas. Untuk itu, seorang guru harus memiliki kemampuan dalam menguasai media maupun metode pembelajaran yang cocok karena hal ini dapat berpengaruh dalam tingkat kemampuan berpikir siswa. Dalam kegiatan pembelajaran, guru diharapkan dapat memilih media pembelajaran yang cocok dan sesuai dengan kondisi kelas maupun kondisi lainnya. Dalam penelitian ini, media pembelajaran yang digunakan adalah media google classroom. Media pembelajaran google classroom akan memberikan inovasi baru dalam menunjang kegiatan pembelajaran, sehingga menimbulkan ketertarikan siswa dan merangsang kemampuan berpikirnya. Media pembelajaran yang digunakan diharapkan dapat juga digunakan siswa dalam berbagai kondisi. Pemilihan media pembelajaran yang tepat diharapkan dapat membuat siswa lebih interaktif, menarik, dan efisien (Tafonao, 2018). Kondisi belajar yang interaktif diharapkan dapat meningkatkan kemampuan berpikir kritis IPA. Media pembelajaran merupakan sarana atau alat yang dapat digunakan untuk menunjang kegiatan belajar dan mengajar (Wati, 2016). Menurut Asyhar (2012) media pembelajaran dapat dipahami sebagai segala sesuatu yang dapat menyampaikan atau menyalurkan pesan dari sumber terencana sehingga terjadi lingkungan belajar yang kondusif.

Media pembelajaran memiliki fungsi yang penting dalam proses pembelajaran. Menurut Amirono dan Daryanto (2016) secara umum kegunaan media pembelajaran antara lain: (1) Memperjelas pesan untuk tidak terlalu verbalistis. (2) Mengatasi keterbatasan ruang, waktu, tenaga, dan daya indra. (3) Menimbulkan gairah belajar. (4) Memungkinkan anak belajar mandiri sesuai bakat dan kemampuan visual, auditori, dan kinestetiknya. (5) Memberi rangsangan yang sama, mempersamakan pengalaman dan menimbulkan persepsi yang sama. (6) Proses pembelajaran mengandung lima komponen komunikasi, guru sebagai komunikator, bahan pembelajaran, media pembelajaran, siswa sebagai komunikan, dan tujuan pembelajaran.

Ada banyak jenis media pembelajaran yang dapat digunakan, salah satu media yang dapat digunakan adalah media pembelajaran google classroom. Media pembelajaran google classroom adalah media pembelajaran online yang dapat memudahkan guru dan siswa dalam menyampaikan materi pembelajaran. Menurut Abdul Barir Hakim dalam Ernawati (2018) media pembelajaran google classroom merupakan layanan berbasis internet yang disediakan oleh google sebagai sebuah sistem e-learning, didesain untuk membantu pengajar membuat dan membagikan tugas kepada 
pelajar secara paperless. Dengan demikian google classroom merupakan suatu aplikasi yang disediakan oleh google untuk menciptakan ruang kelas dalam dunia maya. Aplikasi ini membantu guru dan siswa dalam melaksanakan proses belajar mengajar.

Media google classroom akan membuat pembelajaran lebih efektif, siswa dapat belajar, menyimak, dan mengirim tugas dari jarak jauh. Media pembelajaran google classroom juga cukup efektif digunakan siswa karena tidak banyak memakai data internet, sehingga tidak memberatkan siswa dalam proses pembelajaran yang berlangsung. Dengan adanya era teknologi yang semakin berkembang ini maka program pembelajaran lebih diarahkan untuk bisa memanfaatkan teknologi dengan lebih baik.

Saat ini, mata pelajaran IPA kurang diminati siswa karena penyajian materi pembelajaran yang kurang menarik dan monoton. Materi hanya disampaikan guru secara verbal tanpa memberikan variasi media pembelajaran yang sesuai. Penggunaan media pembelajaran google classroom diharapkan dapat merangsang keterlibatan siswa dalam kegiatan pembelajaran dengan memberikan kesempatan pada siswa untuk bertanya, mengikut-sertakan semua siswa dalam mengungkapkan gagasan maupun memecahkan suatu permasalahan pada topik yang dibicarakan. Tidak hanya berperan sebagai penerima informasi pasif, siswa pun ditantang untuk aktif berkomunikasi, terutama bertanya, menemukan informasi, dan memecahkan masalah yang dihadapi sehingga dapat menjadi solusi yang tepat dalam meningkatkan kemampuan berpikir kritis khususnya pada mata pelajaran IPA. Tujuan penelitian ini adalah untuk mengetahui tingkat kemampuan berpikir kritis IPA melalui penggunaan media google classroom pada siswa kelas VII di SMP Lamaholot Cengkareng.

\section{METODE}

Penelitian ini dilaksanakan di SMP Lamaholot, Cengkareng, Jakarta Barat. Subjek penelitian ini yaitu siswa kelas VII SMP Lamaholot dengan jumlah siswa sebanyak 20 orang. Peneliti mengambil subjek penelitian dari seluruh populasi siswa didalam satu kelas. Objek penelitian yang digunakan adalah kemampuan berpikir kritis IPA pada materi ekosistem dengan menggunakan media pembelajaran google classroom. Penelitian ini mengambil sampel tingkat Sekolah Menengah Pertama (SMP) karena pada tingkatan ini siswa cenderung masih aktif berpikir, aktif mencari tahu materi-materi yang sebelumnya belum pernah mereka dapatkan atau mereka cenderung untuk lebih mendalami secara detail tentang suatu materi pembelajaran yang mereka anggap menarik. Penelitian ini merupakan penelitian kualitatif deskriptif dengan jenis penelitian analisis deskriptif untuk mengetahui gambaran yang jelas mengenai kemampuan berpikir kritis siswa.

Penelitian kualitatif merupakan suatu penelitian yang bertujuan untuk memahami fenomena tentang apa yang dialami oleh subjek penelitian dengan cara deskriptif dalam bentuk kata-kata dan bahasa pada suatu konteks khusus dengan memanfaatkan berbagai metode ilmiah yang memiliki karakteristik: (1) Latar ilmiah, (2) Manusia sebagai alat (instrumen), (3) Metode kualitatif, (4) Analisis data secara induktif, (5) Teori dari dasar (grounded theory), (6) Deskriptif, (7) Lebih mementingkan proses dari pada hasil, (8) Adanya batas yang ditentukan oleh fokus, (9) Adanya kriteria khusus untuk keabsahan data, (10) Desain yang bersifat sementara, (11) Hasil penelitian dirundingkan dan disepakati bersama. Pada penelitian ini ciri penelitian yang digunakan yaitu: manusia sebagai alat (instrumen), menggunakan metode kualitatif, deskriptif yaitu data yang dikumpulkan berupa kata-kata dan gambar, bukan berupa angka-angka, serta adanya batas yang ditentukan oleh fokus. Teknik pengambilan sampel yang digunakan adalah purposive sampling. Teknik purposive sampling adalah teknik penentuan sampel dengan pertimbangan tertentu. Untuk menentukan kelas subjek, peneliti meminta pertimbangan guru berkaitan dengan kemampuan berpikir kritis siswa secara klasikal. Hal ini dilakukan untuk memudahkan peneliti dalam menganalisis kemampuan berpikir kritis subjek.

Dalam penelitian ini dipilih satu kelas karena kelas tersebut dirasa memadai untuk diadakannya penelitian tersebut. Metode pengumpulan data dalam penelitian ini menggunakan 
triangulasi meliputi dokumentasi yang berisi draft tes uraian, wawancara, dan lembar observasi. Tes uraian digunakan untuk mengukur tingkat kemampuan berpikir kritis siswa dalam menyelesaikan soal IPA. Kemampuan berpikir kritis tidak hanya dilihat dari benar atau salah hasil jawaban siswa, tetapi juga dilihat dari kemampuan siswa dalam menyajikan jawaban mereka dengan pemahamanpemahaman yang mereka ketahui. Dalam penelitian ini, peneliti memberikan 10 soal uraian berpikir kritis kepada siswa yang sebelumnya sudah divalidasi ahli oleh dosen pembimbing. Data yang diperoleh kemudian akan dianalisis validitas. Validitas suatu instrumen menunjukkan seberapa jauh seseorang dapat mengukur apa yang hendak diukur. Sebuah tes memiliki validitas isi apabila mengukur tujuan khusus tertentu yang sejajar dengan materi atau isi pelajaran yang diberikan. Validitas isi instrumen tes dalam penelitian ini ditetapkan menurut analisis rasional terhadap isi tes yang penilaiannya atas pertimbangan subjektif individual oleh seseorang yang ahli dibidangnya, yaitu dosen pembimbing. Validitas isi dilakukan dengan menggunakan uji korelasi product moment. Setelah analisis validitas kemudian dilanjutkan dengan analisis reliabilitas. Menurut Sugiono (2008) instrumen yang reliabel adalah instrumen yang bila digunakan beberapa kali untuk mengukur objek yang sama, akan menghasilkan data yang sama. Pengujian reliabilitas dalam penelitian ini akan dilakukan dengan internal consistency reliability, yaitu dilakukan dengan cara mencobakan instrumen sekali saja, kemudian data yang diperoleh dianalisis dengan metode tertentu. Dalam penelitian ini menggunakan instrumen tes berbentuk uraian. Oleh sebab itu, pengujian reliabilitas yang dilakukan adalah pengujian reliabilitas untuk intrumen non diskrit dengan menggunakan rumus Alpha Cronbach. Berikutnya dilakukan uji taraf kesukaran. Taraf kesukaran adalah bilangan yang menunjukkan sukar dan mudahnya suatu soal. Selanjutnya yang terakhir adalah uji daya beda. Daya pembeda soal adalah kemampuan suatu butir soal dapat membedakan antara siswa yang telah menguasai materi yang diujikan dan siswa yang belum menguasai materi yang diujikan. Pengklasifikasian daya beda soal menurut Surapranata (2004) adalah seperti pada tabel 1.

\section{Tabel 1}

Klasifikasi Daya Beda

\begin{tabular}{cc}
\hline Indeks Daya Pembeda & Kriteria \\
\hline $\mathrm{D} \leq 0,10$ & Jelek \\
$0,10<\mathrm{D} \leq 0,30$ & Cukup \\
$\mathrm{D}>0,30$ & Baik \\
\hline
\end{tabular}

Sumber: Mahmuzah, 2015

Instrumen yang selanjutnya adalah pedoman wawancara. Instrumen ini berisikan garis besar pertanyaan-pertanyaan peneliti yang akan diajukan kepada subjek penelitian. Secara umum pengembangan pedoman wawancara yang dimulai dari penyusunan draft penyusunan wawancara, justifikasi instrumen oleh validator berdasarkan kriteria yang telah ditetapkan, yaitu kejelasan butir pertanyaan dan apakah pertanyaan sudah mengarah pada tujuan, revisi berdasarkan temuan dan saran validator, sampai dengan instrumen pedoman wawancara yang siap digunakan. Proses analisis data pada dasarnya melalui tiga tahap analisis sesuai dengan model interactive Sugiono (2008), yaitu reduksi data, penyajian data, dan kesimpulan. Reduksi data merupakan proses berpikir sensitif yang memerlukan kecerdasan, keluasan ke dalam wawasan yang tinggi. Dalam proses penelitian, data yang diperoleh di beberapa lokasi penelitian memungkinkan banyaknya jumlah data yang ada dan tingkat kerumitan semakin tinggi, sehingga proses reduksi data harus segera dilakukan, agar data yang telah direduksi memberikan gambaran yang jelas. Penyajian data dalam penelitian kualitatif, penyajian data dilakukan melalui uraian singkat, bagan hubungan antar kategori, dan sejenisnya. Penyajian data mempermudah dalam memberikan pemahaman mengenai data yang diperoleh dan diolah. Pada penelitian ini, metode yang digunakan adalah deskriptif dengan pendekatan kualitatif sehingga penyajian yang disajikan dalam bentuk uraian atau deskripsikan dalam bentuk kalimat. Penarikan kesimpulan adalah langkah ketiga dalam analisis data kualitaif. Dalam penelitian kualitatif, penarikan kesimpulan dilakukan untuk menjawab rumusan masalah 
sementara, jika kemudian ditemukan data-data lain yang mendukung maka kesimpulan tersebut bisa berubah.

\section{HASIL DAN PEMBAHASAN}

Dalam penelitian ini, peneliti mengambil sampel penelitian kelas VII di SMP Lamaholot Cengkareng Kota Jakarta Barat dengan jumlah siswa sebanyak 20 orang. Penelitian ini dilaksanakan melalui penggunaan media pembelajaran online yaitu media pembelajaran google classroom (Hardiyana, 2015). Tujuan dari penggunaan media pembelajaran google classroom ini adalah untuk memberikan variasi media pembelajaran serta untuk mengetahui tingkat kemampuan berpikir kritis siswa dengan sistem pembelajaran jarak jauh atau online di SMP Lamaholot Cengkareng. Menurut Hammi dalam Nirfayanti (2018) media pembelajaran google classroom merupakan sebuah aplikasi yang memungkinkan ruang kelas di dunia maya. Pada pedoman standart kompetensi mata pelajaran IPA, peneliti melakukan langkah-langkah pembelajaran seperti, menyiapkan materi ekosistem, menyiapkan media pembelajaran online berupa google classroom, menyusun kisi-kisi intrumen tes uraian, menyiapkan instrumen penelitian tes kognitif berupa soal uraian yang berjumlah 10 soal, menguji coba instrumen tes penelitian, menganalisis soal uji coba tersebut untuk menentukan soal mana yang sesuai untuk digunakan dalam penelitian. Tingkat kemampuan berpikir kritis siswa diukur melalui tes uraian, wawancara, dan observasi saat kegiatan pembelajaran berlangsung. Tidak hanya berperan sebagai penerima informasi pasif saja, siswa pun diajak untuk aktif berkomunikasi, kritis dalam menerima informasi yang baru atau pun yang belum diketahuinya secara detail, kritis dalam menemukan informasi dan memecahkan masalah yang dihadapi. Data hasil wawancara menunjukkan bahwa siswa disekolah tersebut sudah cukup kritis dalam proses pembelajaran yang berlangsung. Siswa memiliki inisiatif sendiri untuk bertanya atau mencari tahu secara detail informasi yang diterimanya. Siswa juga cukup antusias dalam menjalani pembelajaran dengan menggunakan media google classroom, hanya saja kesulitan yang sedikit dialami mungkin terjadi pada jaringan atau sinyal beberapa siswa yang kurang baik sehingga lambatnya informasi yang diterima pada beberapa orang siswa. Pada data hasil observasi yang diamati selama proses pembelajaran, siswa terlihat mampu menjawab pertanyaan-pertanyaan yang dilontarkan oleh guru, kritis mendiskusikan argumen yang berbeda dengan teman lainnya, dapat membedakan argumen yang salah dan yang benar, serta terlihat sangat antusias dalam proses pembelajaran. Faktor lain dari proses pembelajaran ini adalah dukungan orang tua. Pada saat proses pembelajaran berlangsung, orang tua ikut aktif dalam mendampingi anak-anaknya sehingga siswa dapat lebih fokus dalam menerima pelajaran yang sedang diberikan.

Data skor tes kemampuan berpikir kritis dianalisis menurut pedoman penskoran yang telah disediakan oleh peneliti. Rata-rata skor hasil tes kognitif siswa akan dikonversi menggunakan penilaian acuan patokan seperti berikut ini:

\section{Tabel 2}

Kriteria Penilaian Acuan dalam Kemampuan Berpikir Kritis IPA

\begin{tabular}{ll}
\hline Presentase & Kategori \\
\hline $81-100$ & Sangat Baik \\
$61-80$ & Baik \\
$41-60$ & Sedang \\
$21-40$ & Buruk \\
$0-20$ & Buruk Sekali \\
\hline
\end{tabular}

Sumber: Riduwan, 2013

Hasil dari tes kognitif siswa dengan nilai rata-rata pada mata pelajaran IPA sebesar 86,8. Nilai tertinggi siswa mencapai 100 dengan presentase $100 \%$ sedangkan nilai tes terendah siswa adalah 62 dengan presentase $62 \%$. Dalam hal ini terlihat dari 20 orang siswa hanya terdapat dua orang siswa yang nilainya dibawah standar ketuntasan minimal. Tentu saja hal ini dapat tertutupi dengan 18 siswa lainnya yang mendapat nilai jauh diatas standar ketuntasan minimal. Bahkan ada 
satu orang siswa yang mendapat nilai sempurna, ini memungkinkan bahwa dikelas ini memiliki tingkat kemampuan berpikir kritis IPA yang sangat tinggi. Untuk mengetahui data tingkat kemampuan berpikir kritis IPA berdasarkan indikator tiap butir soal maka akan disajikan pada Tabel 3.

\section{Tabel 3}

Hasil Analisis Per Indikator Kemampuan Berpikir Kritis IPA dalam Materi Ekosistem

\begin{tabular}{llll}
\hline No. & \multicolumn{1}{c}{ Indikator } & \multicolumn{1}{c}{ Presentase } & \multicolumn{1}{c}{ Kategori } \\
\hline 1 & Memberikan penjelasan sederhana & $87,5 \%$ & Sangat Baik \\
2 & Membangun keterampilan dasar & $89,5 \%$ & Sangat Baik \\
3 & Penarikan kesimpulan & $80,25 \%$ & Baik \\
4 & Memberikan penjelasan lebih lanjut & $86 \%$ & Sangat Baik \\
5 & Mengatur strategi dan taktik & $92 \%$ & Sangat Baik \\
\hline
\end{tabular}

Berdasarkan tabel 3, terdapat empat indikator yang mendapat kategori sangat baik dan satu indikator yang mendapat kategori baik. Indikator yang mendapat kategori sangat baik adalah mengatur strategi dan taktik dengan presentase $92 \%$, indikator membangun keterampilan dasar dengan presentase $89,5 \%$, indikator memberikan penjelasan sederhana dengan presentase $87,5 \%$, dan memberikan penjelasan lebih lanjut dengan presentase $86 \%$. Sedangkan indikator yang mendapat kategori baik yaitu indikator penarikan kesimpulan dengan presentase $80,25 \%$. Hal tersebut didukung oleh keaktifan siswa dalam proses pembelajaran yang berlangsung sehingga berdampak positif pada tingkat kemampuan berpikir kritis IPA yang tinggi. Tingkat kemampuan berpikir kritis IPA yang tinggi diikuti dengan tanggapan siswa yang kritis dalam bertanya dan menggali secara detail informasi yang diterima sesuai dengan materi yang sedang diberikan saat itu. Siswa juga tidak segan untuk bertukar informasi kepada sesama teman sekelasnya. Begitu pula hasil yang didapat saat wawancara dan observasi yang berlangsung selama pembelajaran, penerapan media pembelajaran online google classroom dalam proses pembelajaran ekosistem berjalan dengan cukup baik sesuai dengan yang diharapkan. Hal ini menunjukkan siswa tersebut sangat mampu untuk mengikuti pembelajaran dengan media pembelajaran google classroom, dapat memahami materi ekosistem dengan sangat baik, dimana mereka dapat menganalisis pertanyaan-pertanyaan yang diberikan. Hal ini sesuai dengan pendapat Dawey dalam Luzyawati (2017) dan Nugraha (2018) yang mendefinisikan berpikir kritis sebagai berpikir reflektif yaitu pertimbangan yang aktif, persistent (terus-menerus), dan teliti mengenai sebuah keyakinan atau bentuk pengetahuan yang diterima begitu saja dipandang dari sudut alasan-alasan yang mendukungnya dan kesimpulankesimpulan lanjutan yang menjadi kecenderungannya. Berdasarkan hasil rekapitulasi dari hasil pengamatan dan data yang diperoleh selama penelitian menunjukkan bahwa kemampuan berpikir kritis IPA melalui penggunaan media pembelajaran google classroom di SMP Lamaholot Cengkareng memiliki hasil rata-rata 86,8 dengan kategori sangat baik.

\section{KESIMPULAN}

Berdasarkan hasil penelitian dan analisis yang telah dilakukan di SMP Lamaholot Cengkareng, dapat disimpulkan bahwa kemampuan berpikir kritis IPA pada materi ekosistem dengan menggunakan media google classroom pada siswa kelas VII di SMP Lamaholot Cengkareng memperoleh hasil keseluruhan yang sangat baik. Hasil kemampuan berpikir kritis dari 20 siswa menunjukkan rata-rata $75 \%$ siswa berada pada kategori sangat baik yang termasuk dalam indikator mengatur strategi dan taktik, memberi penjelasan sederhana, membangun keterampilan dasar dan memberi penjelasan lebih lanjut. Sedangkan dan $25 \%$ siswa lainnya berada pada kategori baik yang termasuk dalam indikator penarikan kesimpulan. Dimana jika dipersentasekan masingmasing tiap indikator berpikir kritis akan didapat data, yaitu indikator memberi penjelasan sederhana memperoleh presentase $87,5 \%$ (sangat baik), indikator berpikir kritis membangun keterampilan dasar memiliki presentase $89,5 \%$ (sangat baik), indikator berpikir kritis penarikan kesimpulan memperoleh presentase paling kecil dibandingkan dengan indikator lainnya yaitu 
sebesar $80,25 \%$ (baik), indikator berpikir kritis memberi penjelasan lebih lanjut memperoleh presentase $86 \%$ (sangat baik), dan indikator berpikir kritis mengatur strategi dan taktik memperoleh presentase sebesar 92\% (sangat baik) dimana pencapaian indikator ini paling tinggi dibandingkan indikator lainnya. Sehingga diperoleh keseluruhan rata-rata kemampuan berpikir kritis siswa kelas VII SMP Lamaholot Cengkareng yaitu 86,8 atau dengan presentase sebesar $87,05 \%$ dengan kategori sangat baik.

\section{DAFTAR PUSTAKA}

Amirono \& Daryanto. (2016). Evaluasi dan Penilaian Pembelajaran Kurikulum 2013. Yogyakarta: Gava Media.

Arikunto, S. (2009). Dasar-Dasar Evaluasi Pendidikan (edisi revisi). Jakarta: Bumi Aksara.

Asyhar, R. (2012). Kreatif Mengembangkan Media Pembelajaran. Jakarta: Gaung Persada (GP) Press.

Ernawati. (2018). Pengaruh Penggunaan Aplikasi Google Classroom Terhadap Kualitas Pembelajaran dan Hasil Belajar Siswa Pada Mata Pelajaran Ekonomi Kelas XI di MAN 1 Kota Tangerang Selatan. Jakarta: Universitas Islam Negeri Syarif Hidayatullah.

Hardiyana, A. (2015). Implementasi Google Classroom sebagai Alternatif dalam Meningkatkan Mutu Pembelajaran di Sekolah (Karya Tulis Ilmiah), SMA Negeri 1 Losari, Cirebon.

Luzyawati, L. (2017). Analisis Kemampuan Berpikir Kritis Siswa SMA Materi Alat Indera Melalui Model Pembelajaran Inquiry Pictorial Riddle. Jurnal Pendidikan Sains dan Matematika, 5(2), 9-21.

Mahmuzah, R. (2015). Peningkatan Kemampuan Berpikir Kritis Siswa SMP Melalui Pendekatan Problem Possing. Jurnal Peluang, 4(1), 64-72.

Moleong, L. (2002). Metode Penelitian Kualitatif. Bandung: Remaja Rosdakarya.

Nirfayanti. (2018). Pengaruh Media Pembelajaran Google Classroom dalam Pembelajaran Analisis Real Terhadap Motivasi Belajar Mahasiswa. Jurnal Penelitian Matematika dan Pendidikan Matematika, 2(1), 50-59.

Nugraha, W.S. (2018). Peningkatan Kemampuan Berpikir Kritis dan Penguasaan Konsep IPA Siswa SD dengan Menggunakan Model Problem Based Learning. Jurnal Pendidikan Dasar, 10(2), 115-127.

Riduwan. (2013). Dasar-Dasar Statistik. Bandung: Alfabeta.

Sugiono. (2008). Metode Penelitian Pendidikan Pendekatan Kuantitatif, Kualitatif, dan R\&D. Bandung: Alfabeta.Surapranata. (2004). Analisis, Validitas, Reliabilitas, dan Interpretasi Hasil Tes. Bandung: Rosda.

Tafonao, T. (2018). Peran Media Pembelajaran dalam Meningkatkan Minat Belajar Mahasiswa. Jurnal Komunikasi Pendidikan, 2(2), 103-114

Wati, E.R. (2016). Ragam Media Pembelajaran. Yogyakarta: Kata Pena.

Wijaya, C. (2010). Pendidikan Remidial: Sarana Pengembangan Mutu Sumber Daya Manusia. Bandung: Remaja Rosdakarya. 